\title{
Phase II trials of conjugates of S.typhi Vi and of S.paratyphi A O-Specific polysaccharide (O-SP) conjugates in Dong Thap province, Vietnam
}

S.C. Szu, Z. Kossaczka, E. Konadu, A. Karpas, J. Shiloach, D.A. Bryla, F.Y.C. Lin, J.B. Robbins, D.D. Trach ${ }^{1}$, H.B. Khiem², V.A. Ho ${ }^{3}$, N.T.T. Thuy ${ }^{2}$,

\begin{abstract}
Abstrak
$V i$ konjugat, yang dibuat menggunakan SPDP sebagai linker, menghasilkan anti-Vi dengan kadar lebih tinggi di dalam total serum daripada Vi saja pada sukarelawan (US army). Vi konjugat menggunakan karier rekombinan eksoprotein $A(r E P A)$ dari $\mathrm{P}$. aeruginosa menghasilkan anti-Vi dengan kadar lebih tinggi daripada yang menggunakan subunit $B$ toksin $\mathrm{E}$. coli heat labile. Untuk mempelajari $V i$ konjugat pada anak-anak, $V i$ dikonjugasikan dengan rEPA menggunakan SPDP (I) atau ADH (II) sebagai linkers. Keamanan dan imunogenitas kedua Vi-rEPA konjugat dibandingkan dengan Vi saja pada 157 anak berumur 5-14 tahun. Setelah satu suntikan, tidak terdapat reaksi sampingan yang serius. ELISA serum anti-Vi menunjukkan semua vaksin memberikan respon IgG anti-Vi dengan kenaikan $>4$ kali. Konjugat II memberikan kadar IgG anti-Vi lebih tinggi daripada konjugat I dan Vi (169 vs 18,9; 22,8). Kedua konjugat tersebut memberikan kadar IgM anti-Vi lebih tinggi daripada Vi sendiri. Selanjutnya, 210 anak berumur 2-4 tahun diinjeksi dengan satu atau dua dosis dari salah satu konjugat, berjarak waktu 6 minggu: tidak ditemukan reaksi sampingan. Enam minggu setelah suntikan pertama, semua anak memberikan respon kenaikan >4 kali IgG anti-Vi, mirip dengan hasil yang diperoleh untuk anak umur 5-14 tahun, konjugat II memberikan kadar IgG anti-Vi lebih tinggi setelah satu suntikan $(77,2$ vs 30,2$)$. Suntikan kedua dari kedua konjugat tersebut menginduksi peningkatan respon: konjugat I, 83,0 vs 21,4, konjugat II, 95,4 vs 69,9. Enam bulan setelah suntikan pertama, kadar IgG anti-Vi menurun, tetapi lebih tinggi daripada kadar pre vaksinasi. Penyebab kedua tersering demam enterik di Asia tenggara, S. paratyphi $A$, adalah kuman patogen dan manusia adalah satu-satunya pejamu. Konjugat-konjugat dibuat dengan aktivasi O-SP dengan CDAP dan ikatan langsung (I) atau melalui ADH (II) pada toxoid tetanus (TT). Pada fase I dan II dari percobaan klinik konjugat S. paratyphi A -TT tidak menginduksi reaksi sampingan. Lebih dari 80\% sukarelawan (18 dewasa dan 108 orang berumur 13-17 tahun) memberikan respon kenaikan $>4$ kali IgG anti-LPS. Konjugat I memberikan kadar antibodi lebih tinggi daripada konjugat II. Konjugat I disuntikkan pada 96 anak berumur 2-4 tahun satu atau dua kali, berjarak waktu 6 minggu: tidak satupun vaksin memberikan reaksi sampingan yang bermakna. Setelah satu suntikan $87 \%$ orang memberikan kenaikan $>4$ kali $1 g G$ anti-LPS dengan peningkatan respon setelah suntikan kedua. Fase ketiga percobaan Vi-rEPA konjugat I dan S. paratyphi A-TT (ikatan langsung) direncanakan untuk anak berumur $2-5$ di Vietnam.
\end{abstract}

\begin{abstract}
$V i$ conjugates, prepared with SPDP as a linker, elicited higher levels of total serum anti-Vi than Vi alone in recruits in the U.S. army. Vi conjugate using carrier $\mathrm{P}$. aeruginosa recombinant exoprotein A ( $\mathrm{rEPA}$ ) elicited higher levels of anti-Vi than those with the $B$ subunit of the heat labile toxin of $\mathrm{E}$. coli. To study Vi conjugates in children, Vi was conjugated to $r E P A$ by using SPDP (I) or ADH (II) as linkers. The safety and immunogenicity of the two Vi-rEPA conjugates were compared with Vi alone in 1575 -14 year olds. After one

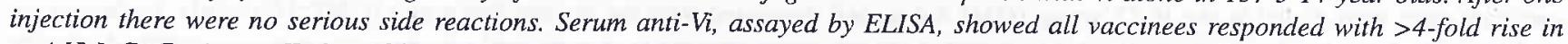
anti-Vi IgG. Conjugate II elicited higher levels of anti-Vi IgG than conjugate I or Vi (169vs 18.9, 22.8). Both conjugates elicited higher IgM anti-Vi than Vi alone. Subsequently, $2102-4$ year olds were injected with one or two doses of either conjugate six weeks apart: no side reactions were reported. Six weeks after the first injection, all children responded with $>4$-fold rise in IgG anti-Vi. Similar to the results in 5-14 year olds, conjugate II elicited higher IgG anti-Vi levels after one injection (77.2 vs 30.2). The second injection of both conjugates induced booster responses: for conjugate I, 83.0 vs 21.4, for conjugate II, 95.4 vs 69.9. Six months after the first injection, the IgG anti-Vi levels declined but remained well above the pre-vaccination level. The second most common cause of enteric fever in Southeast Asia, S. paratyphi $A$, is a pathogen and inhabitant of humans only. Conjugates were prepared by activation of the O-SP with $C D A P$ and binding directly (I) or through ADH (II) to tetanus toxoid (TT). In phase I and II clinical trials S. paratyphi $A-T T$ conjugates induced no side reactions. More than 80\% volunteers (18 adults and 108 13-17 year olds) responded with >4-fold rise in IgG anti-LPS. Conjugate I elicited higher antibodies than conjugate II. Conjugate I was injected into 96 2-4 year old children one or two times six weeks apart: none of the vaccinees had significant side reactions. After one injection $87 \%$ reacted with $>4$-fold rise in their anti-LPS $\operatorname{IgG}$ with a booster response after the second injection. Phase 3 trials of Vi-rEPA conjugate I and of S. paratyphi A-TT (directly bound) are planned for 2-5 year olds in Vietnam.
\end{abstract}

National Institutes of Health, Bethesda, Maryland, USA

${ }^{1}$ National Institute of Hygiene and Epidemiology

${ }^{2}$ Pasteur Institute of Ho Chi Minh City

${ }^{3}$ Huu Nghi Hospital, Vietnam. 